\title{
Do female commissioners have higher social responsibility? Research in manufacturing companies in Indonesia
}

\author{
Nuria Fahmi,Vidya Vitta Adhivina ${ }^{1}$ \\ Universitas PGRI Yogyakarta Indonesia
}

\begin{abstract}
This study aims to test the slack resources and feminism of the board on the quality of corporate social responsibility disclosure. The population of this study is all companies listed on the Indonesian Stock Exchange during the 2014-2016 period. The data are collected by using the official IDX website. From this research, there were 539 companies listed in 2016, 525 companies listed in 2015 and 498 companies listed in 2014. This research consists of 75 companies that published a sustainability report. The purposive sampling technique used for selecting the sample. The results of this study found that the slack resources and the feminism of the director has no significant effect on the quality of CSR disclosure while the feminism of commissioners has a negative impact on the quality of CSR disclosure.
\end{abstract}

Keyword: corporate social responsibility disclosure, slack resources, feminism

\section{Background}

To survive, companies must care about environment where the company do their operation. The company's concern about environment implemented in Corporate Social Responsibility (CSR). CSR can be formed as environmental preservation, waste management, building community welfare that giving benefits to the community (Luthan et al., 2017). CSR can be implemented directly by companies under the human resource development or public relations division. Corporate social responsibility can also be carried out by foundations who formed separately from the organization but still having responsibility to the Chief Operating Officer (CEO) or the Board of Directors (BOD). In Indonesia, most companies perform their CSR through collaboration with other partners such as NGOs, universities or consulting institutions (Sudana \& Arlindania, 2011).

Many research has linked CSR with the company value (Hermawan \& Maf'ulah, 2014; Triyono \& Setyadi, 2015; Adriani, 2016), organizational performance (Setianingsih \& Setyadi 2014; Amalia \& Sularto, 2014) and organizational ownership (Sari \& Rani, 2015; Edison, 2017). However, research on CSR still interesting because first, the company is not only responsible for the quality of products or services but also the quality of the environment in which the company operates (Monks \& Minow, 2011). Second, there is no adequate legality regarding CSR reporting, especially in Asian countries so that the quality of CSR information is still low (Fatima et al., 2015; Jain \& Thomson, 2015). Third, the findings of some previous research were inconsistent. Some researchers state that the slack resources, feminism of the board of commissioners and board of directors influence the quality of CSR disclosure (Anggraeni \& Djakman 2017; Yusuf et al., 2017; Setiawan et al.,

\footnotetext{
${ }^{1}$ Corresponding author: adhivina@upy.ac.id
} 
2018). Other findings state that slack resources, feminism of the board of commissioners and board of directors have no significant effect on CSR disclosure (Rohmah, 2015; Sudana \& Arlindania, 2011; Darus et al., 2014).

\section{Hypotheses development}

The resource-based theory states that the board is one of the resources owned to manage the company well by the assigned tasks because the board is representation of the interests of shareholders and other stakeholders so that the identity of the committee will determine what kind of policies used by the company. The board identity which used in this study is board feminism. The representation of women in the ranks of the board is the latest issue related to corporate governance. If corporate governance stays more effective, it will increased company's attention into the matters referred to corporate sustainability, such as environmental, social and community issues which cannot be denied when these issues become one of the strategic problems in supporting survival company (Anggraeni \& Djakman, 2017).

Table 1. Previous research

\begin{tabular}{|c|c|c|c|}
\hline No & Author & Sample & Result \\
\hline 1 & $\begin{array}{l}\text { Anggraeni \& } \\
\text { Djakman } \\
(2017)\end{array}$ & $\begin{array}{l}\text { The sample consisted of } 114 \\
\text { companies on the IDX for the period } \\
\text { 2012-2014. }\end{array}$ & $\begin{array}{l}\text { Slack resources have a positive influence on } \\
\text { CSR disclosure and feminism of the board of } \\
\text { commissioners, the board of directors } \\
\text { negatively influences on CSR disclosure. }\end{array}$ \\
\hline 2 & $\begin{array}{l}\text { Yusuf et al. } \\
(2017)\end{array}$ & $\begin{array}{l}\text { The sample consisted of } 114 \\
\text { companies on the IDX for the period } \\
\text { 2011-2013. }\end{array}$ & $\begin{array}{l}\text { Slack resources, company } \\
\text { commissioner size }\end{array}$ have $\begin{array}{r}\text { and } \\
\text { significantly } \\
\text { influence on corporate social responsibility } \\
\text { disclosure. }\end{array}$ \\
\hline 3 & $\begin{array}{l}\text { Pradnyani \& } \\
\text { Sisdyani } \\
(2015)\end{array}$ & $\begin{array}{l}\text { The sample consisted of } 66 \\
\text { manufacturing companies on the } \\
\text { IDX for the period 2011-2013. }\end{array}$ & $\begin{array}{l}\text { Profitability and board of commissioners' size } \\
\text { have a positive effect on CSR, while company } \\
\text { size and leverage have no significant effect on } \\
\text { CSR. }\end{array}$ \\
\hline 4 & $\begin{array}{l}\text { Rohmah } \\
(2015)\end{array}$ & 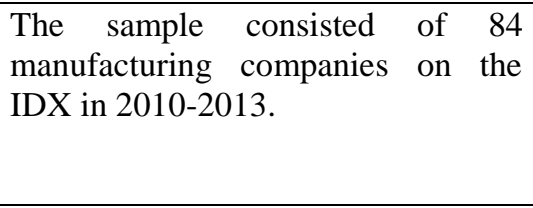 & $\begin{array}{l}\text { Independent boards and foreign ownership } \\
\text { have no significant effect on CSR disclosure, } \\
\text { while institutional ownership, company size } \\
\text { and profitability have a significant effect on } \\
\text { CSR. }\end{array}$ \\
\hline 5 & $\begin{array}{l}\text { Fariati \& } \\
\text { Segoro }(2013)\end{array}$ & $\begin{array}{l}\text { The sample consisted of } 66 \text { chemical } \\
\text { industry companies on the IDX in the } \\
\text { period } 2010-2011 \text {. }\end{array}$ & $\begin{array}{l}\text { Firm size, profitability and board board size } \\
\text { have a significant effect on social } \\
\text { responsibility disclosure. }\end{array}$ \\
\hline 6 & $\begin{array}{l}\text { Sudana } \quad \& \\
\text { Arlindania } \\
(2011)\end{array}$ & $\begin{array}{l}\text { The sample consists of all companies } \\
\text { that disclose CSR activities in the } \\
\text { annual report on the IDX 2007-2009. }\end{array}$ & $\begin{array}{l}\text { The board of directors of women and DER has } \\
\text { no significant effect on CSR disclosure, while } \\
\text { the board of directors of foreign citizens, the } \\
\text { size of the board of commissioners and } \\
\text { profitability have a significant impact on CSR. }\end{array}$ \\
\hline 7 & $\begin{array}{l}\text { Setiawan et al. } \\
(2018)\end{array}$ & $\begin{array}{l}\text { The sample consisted of } 106 \text { mining } \\
\text { companies on the Indonesia Stock } \\
\text { Exchange 2013-2015. }\end{array}$ & $\begin{array}{l}\text { The tenure, the director's feminism and the } \\
\text { size of the board of directors have a positive } \\
\text { effect on CSR, while foreign directors have a } \\
\text { negative effect on CSR. }\end{array}$ \\
\hline
\end{tabular}

Companies that have slack resources are expected to have a better quality of CSR disclosure because the company will implement CSR investments which more than companies that have a little (or no) slack resources, if the company care about CSR, the 
company will consider to comply regulations determined by government. CSR activities in the company must allocate certain funds and specific resources to be implemented correctly and adequately. When all events have been carried out, the company has sufficient data and information to be presented in the form of CSR reports. Then, the report used by investors and public to find out the implementation of CSR (Anggraeni \& Djakman, 2017). Implementation of voluntary environmental disclosure activities and slack resources can encourage organizations to do more disclosure because funds are available to meet their administrative costs. The results of this test show that slack resources have a significant positive effect on CSR disclosure (Yusuf et al., 2017). Based on previous research the following hypothesis was proposed:

$H_{1}$ : $\quad$ Slack resources have a positive effect on the quality of CSR disclosure.

According to Setiawan et al. (2018) tenure, the director's gender, the size of the board of directors and foreign directors influence the disclosure of CSR, and it because the directors who have a long term will get more knowledge about the company. The experience and the expertise possessed by the board of directors can consider better results in making decisions. The existence of female director is also expected to provide value added to the company because female directors are more detailed in controlling the implementation of CSR. The Indonesian state adheres to the continental European legal system that has a twotier system, where board members are appointed and can be replaced at any time by the board of directors. The board of directors must also provide information to the board of commissioners so that the performance of the board of directors can be accountable to the board of commissioners (Sari et al., 2013). Sudana \& Arlindania (2011) states that there is no significant effect between the presence of female members of the board of directors and disclosure of CSR, it because a woman's board of directors is more comfortable yielding men in decision making. Based on previous research the following hypothesis was proposed:

$\mathrm{H}_{2}$ : $\quad$ Feminism in directors has a positive effect on the quality of CSR disclosure

According to Yusuf et al. (2017), the board of commissioners plays an essential role in directing the strategy and overseeing the development of the company and ensuring that managers improve the performance of the company as part of the goals set by the company. Rohmah (2015) states that companies that have an independent board of commissioners tend to be more sensitive to social performance and prevent actions that cause environmental violations. Environmental violations will look like a deficiency of concern and awareness of the company about the importance of maintaining the environment, both for the company and the community. The results of this study indicate that the independent board of commissioners does not influence the disclosure of corporate social responsibility. The increase in the number of board of commissioners will easily encourage management to disclose one of the company's obligations. The test results show that the size of the board of commissioners has a positive influence on CSR (Pradnyani and Sisdyani, 2015).

The board of commissioners has the authority that can provide a strong enough influence to pressure management to disclose social responsibility. The bigger the proportion of board of commissioners, the larger parties can supervise the administration, so there will be a lot of detailed information to be presented in the annual report. The results of the study 
show that the size of the board of commissioners has a positive effect on CSR disclosure (Fariati \& Segoro, 2013; Sudana \& Arlindania 2011). While Anggraeni \& Djakman (2017) express a negative relationship. Based on previous research the following hypothesis was proposed:

H3: Feminism in the board of commissioners has a negative effect on CSR disclosure

\section{Method}

The population in this study are all companies listed on the Indonesia Stock Exchange (IDX) during the 2014-2016 period through the site www.idx.co.id. This research was conducted on companies in Indonesia because the proportion of women occupying board functions has a high percentage compared to other countries in Asia (Anggraeni \& Djakman, 2017). The sample selection is made by purposive sampling technique that is sampling technique with specific criteria (Budiarto, 2019). The research sample criteria are:

1. Companies are listed on the IDX during the 2014-2016 period;

2. The company publishes a sustainability report for 2014, 2015 and 2016 periods;

3. The company publishes sustainability reports by applying the fourth generation GRI or G4.

Based on the above criteria, obtained company data with a research period of 3 years so that the sample collected by researchers amounted to 75 observational data, with the following process:

Table 2. Sample selection

\begin{tabular}{lc}
\hline & Companies \\
\hline Registered on the IDX during the 2014-2016 period & 498 \\
a. 2014 & 525 \\
b. 2015 & 539 \\
c. 2016 & \\
Companies that publish sustainability reports and have \\
complete data in the year: \\
a. 2014 & 26 \\
b. 2015 & 25 \\
c. 2016 & 24 \\
\hline Number of observations (company-year) & 75 \\
\hline Source: Secondary data processed in 2018
\end{tabular}

Source: Secondary data processed in 2018

\section{Variable measurement}

\section{Corporate social responsibility}

This study uses the quality of CSR information disclosure as the dependent variable. The quality of CSR disclosure proxied by the index value of information on the three main pillars of CSR, namely economic, environmental, and social in the sustainability report. CSR information refers to the fourth generation GRI indicator (G4) because GRI is one of the reporters of the sustainability report framework and has been widely used by companies and organizations throughout the world (Anggraeni \& Djakman, 2017). This variable is measured by the content analysis method, which is a method of codifying text with the same characteristics to be written in various groups (categories) depending on the specified criteria (Sembiring, 2005). The measurement scale for CSR disclosure is nominal scale (dummy), 
which means that each CSR item in the research instrument given a value of 1 if disclosed and a value of 0 if not disclosed. The score for each piece is summed to get the overall score for each company. The formula shows as follows:

$$
\text { CSRIi }=\frac{\sum x i}{N}
$$

\section{Slack resources}

High-discretion slack shows extra resources that are very easy to use for various discretion managers. Therefore, this study uses high-discretion slack as measured by cash value and cash equivalents as a proxy for the presence of slack resources. The amount of cash and cash equivalents is transformed into natural logarithms of cash and cash equivalents (Anggraeni \& Djakman, 2017).

\section{The feminism of board members}

Board feminism is proxied by gender diversification in board members. This variable is calculated using a comparison of the proportion of women in the board of directors and board of commissioners to the total directors and board of commissioners of a company (Anggraeni \& Djakman, 2017). Calculations on this variable are as follows:

$$
\begin{aligned}
& \text { GD_DIR }=\frac{\text { W_DIR }}{\text { SUM_KOM }} \\
& \text { GD_KOM }=\frac{\text { W_KOM }}{\text { SUM_DIR }}
\end{aligned}
$$

\section{Results and discussion}

Based on the results of observations during the 2014-2016 period ( 3 years), 75 companies were selected as research samples. The results of the study were then tested to prove the hypothesis shown in table 3.

Tabel 3. Hypothesis result

\begin{tabular}{lcclll}
\hline & Beta & Tolerance & VIF & Sig & Result \\
\hline Slack resources (x1) & 0,024 & 0,883 & 1.132 & 0.617 & $\mathrm{H}_{1}:$ rejected \\
Feminism of director (x2) & $-0,231$ & 0,948 & 1.055 & 0.170 & $\mathrm{H}_{2}:$ rejected \\
Feminism of commissioner (x3) & $-0,892$ & 0.898 & 1.113 & $0.008^{*}$ & $\mathrm{H}_{3}$ : accepted \\
\hline $\mathrm{F}=3.984$ & & & & $0.011^{*}$ & \\
Adj $\mathrm{R}^{2}=0.114$ & & & & \\
$\mathrm{DW}=0.283$ & & & & &
\end{tabular}




\section{Classic assumption test}

The test results show that the data are normally distributed and there is no heteroscedasticity (Figure 1).

Figure 1. the test of normality and heteroscedasticity
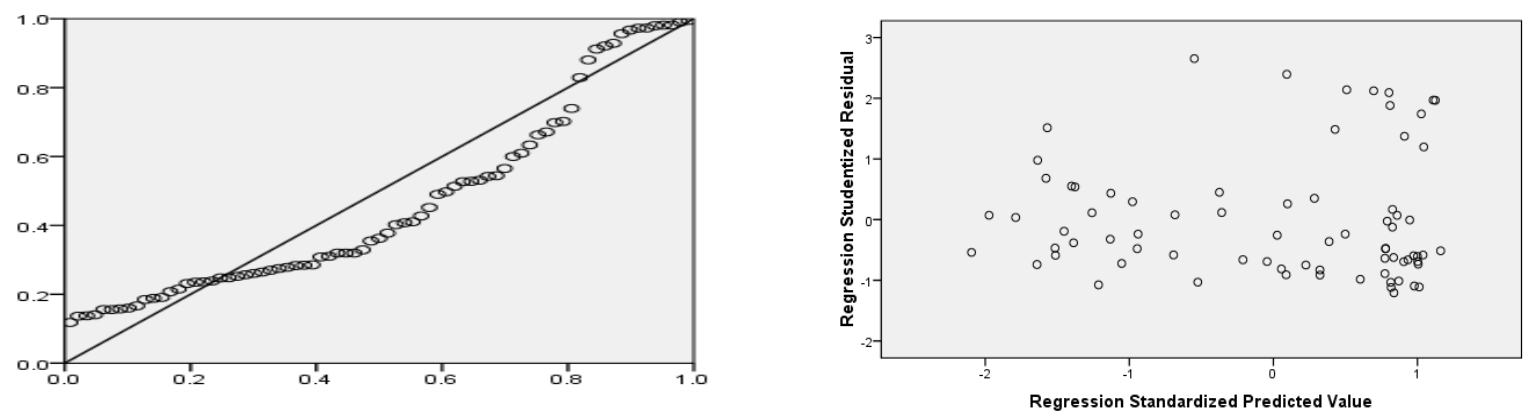

Based on the multicollinearity test (table 3 ) it can be seen that the independent variable has a tolerance value $>0.1$ and the VIF value $<10$ means that there is no multicollinearity. The autocorrelation test results show the amount of Durbin Watson (DW) of 0.283, means that there is no autocorrelation.

\section{Discussion}

Slack resources are more resources that can be used by companies for certain conditions, such as increased resources that can support the success of the company and the development of quality resources to be better. The results of this study indicate that slack resources have no significant impact on the quality of CSR disclosure. This study supports previous research, conducted by Darus et al. (2014) who examined the effect of slack resources on disclosure of CSR in the financial industry in Malaysia. The results show that the higher the slack resources the company have, the lower the CSR information disclosed. It happens because of the strict regulation for the type of industry so that the type of industry tends to focus on managing liquidity rather than CSR activities. Companies with high slack resources will tend to use it for business expansion, not for making environmental investments that have significant costs so the CSR information disclosed by the company will stuck on deficient (Xu et al., 2015). However, the results of this study rejecting the research of Anggraeni \& Djakman (2017) and Yusuf et al. (2017) which states that slack resources have a positive effect on the quality of CSR disclosure.

The results of this study indicate that the board of directors' feminism does not influence the quality of CSR disclosure, it means that hypothesis 2 is rejected. These results indicate that the board of directors as an executing function cannot be a determinant of the quality of CSR disclosure. This result shows the same result of Anggraeni \& Djakman (2017) which states that the board of directors' feminism does not influence the quality of CSR disclosure. The research by Sudana \& Arlindania (2011) states that this might be caused by 
cultural factors in Indonesia, where women have a relaxed attitude to respect male decisions, and there are still a few ranks of women who occupy top positions, so women have less role in taking a decision. The board of directors of women in Indonesia is still experiencing many obstacles because the number of women on the board of directors is very tiny, where a male board of directors still dominates the board of directors.

The results showed that the board of commissioners' feminism has a negative effect on the quality of CSR disclosures. Negative influence is likely because the female board of commissioners does not have sufficient comprehension and expertise regarding the importance of CSR, so they assume that CSR is not too important to implement. Besides, there is a possibility that the female board of commissioners has a kinship relationship with the company so that it can protect the interests of the company (Margaretha \& Isnaini, 2014). Besides, the negative influence is due to the slow decision-making due to the emotional nature of female commissioners which decreases the quality of decisions (Anggraeni \& Djakman, 2017).

\section{Conclusions, limitations and suggestions}

Based on the results of the study, it can be concluded that the slack resources and feminism of the board of directors do not influence the quality of CSR disclosures, while the board of feminism has a significant negative effect on the quality of CSR disclosure. The limitation of this study is the number of samples used in the study because it only uses companies that apply the sustainability report in 2014-2016 thus limiting the generalization of research results. For further research, it can expand the scope of the study sample, so that the results of the study are more accurate. The second limitation is still using the GRI indicator in determining the CSR index, for further research it can involve experts in evaluating the disclosure of Corporate CSR, as well as comparing expert opinions with the opinions of researchers (Yusuf et al., 2017). The third limitation is the number of variables used, for further research it can use top management feminism (audit committee), and top management expertise as variables that might influence CSR (Anggraeni \& Djakman, 2017; Velte, 2016).

\section{REFERENCES}

Adriani, A (2016) Pengaruh tanggung jawab sosial perusahaan terhadap kualitas pengungkapan informasi tanggung jawab sosial dan dampaknya pada nilai perusahaan (Studi empiris pada perusahaan publik di Bursa Efek Indonesia). Jurnal Wawasan Majanemen, 3(1), 15-31

Amalia, S.N., \& Sularto, L. (2014). Analisa pengaruh kinerja keuangan terhadap pengungkapan corporate social responsibility pada perusahaan farmasi yang terdaftar di BEI periode 2010-2013. Account: Jurnal Akuntansi Keuangan dan Perbangkan, 1(2), 136-143.

Anggraeni, D.Y., \& Djakman, C.D. (2017). Slack resources, feminisme dewan dan kualitas pengungkapan tanggung jawab sosial perusahaan. Jurnal Akuntansi dan Keuangan Indonesia, 14(1), 94-118. 
Budiarto, D.S. (2019). Panduan Riset Kuantitatif: Trik Publikasi bagi Pemula. Edisi 1, Penerbit UPY-Press. Yogyakarta

Darus, F., S. Mad., \& Yusof. (2014). The importance of ownership monitoring and firm resources on corporate social responsibility CSR of financial institutions. Procedia Social and Beavioral Sciences, 145, 173-180.

Edison, A. (2017). Struktur kepemilikan asing, kepemilikan institusional dan kepemilikan manajerial pengaruhnya terhadap luas pengungkapan corporate social responsibility (CSR) (studi empiris pada perusahaan sektor utama yang terdaftar di Bursa Efek Indonesia tahun 2013 - 2014). Bisma: Jurnal Bisnis dan Manajemen, 11(2), 164-175.

Fariati., \& Segoro, W. (2013). Pengaruh ukuran entitas, profitabilitas, leverage dan ukuran dewan komisaris terhadap pengungkapan tanggung jawab sosial pada entitas industri dasar dan kimia yang terdaftar di BEI periode 2010-2011. Proceeding PESAT, 5, 278286.

Fatima, A.H., Abdullah, N., \& Sulaiman, M. (2015). Environmental disclosure quality: Examining the impact of the Stock Exchange of Malaysia's Listing requirements. Social Responsibility Journal, 11(4), 904-922.

Hermawan, S., \& Maf'ulah, A.N. (2014). Pengaruh kinerja keuangan terhadap nilai perusahaan dengan pengungkapan Corporate Social Responsibility sebagai variabel pemoderasi. Jurnal Dinamika Akuntansi, 6(2), 103-118.

Luthan, E., Rizki, S.A., \& Edmawati, S.D. (2017). Pengaruh pengungkapan tanggung jawab sosial perusahaan terhadap kinerja keuangan. Jurnal Ekonomi dan Keuangan, 1(2), 204-219.

Jain, A.M.K., \& Thomson, D. (2015). Voluntary CSR disclosure works! Evidence from Asia-Pacific Banks. Social Responsibility Journal, 11(1), 2-18.

Margaretha, F., \& Isnaini, R. (2014). Board diversity and gender composition on corporate social responbility and firm reputation in Indonesia. Jurnal Manajemen dan Kewirausahaan, 16(1), 1-8.

Monks, R.A.G., \& Minow, N. (2011). Corporate Governance, 5th Edition. New Jersey, US: John Wiley and Sons

Pradnyani I.G.A.A., \& Sisdyani. E.A. (2015). Pengaruh ukuran perusahaan, profitabilitas, leverage, dan ukuran dewan komisaris pada pengungkapan tanggung jawab sosial perusahaan. Jurnal Akuntansi, 11(2), 384-397.

Rohmah, D. (2015). Faktor-Faktor yang mempengaruhi pengungkapan corporate social responsibility di dalam laporan sustainability (Studi empiris pada perusahaan yang listing di Bursa Efek Indonesia tahun 2010-2013). Jurnal Bisnis dan Manajemen, 5(2), 243-262.

Sari, W.N., \& Rani, P. (2015) Pengaruh kepemilikan institusional, kepemilikan manajerial, return on assets (ROA) dan ukuran perusahaan terhadap pengungkapan corporate social responsibility (CSR) pada perusahaan manufaktur yang terdaftar di Bursa Efek Indonesia periode 2011-2013. Jurnal Akuntansi dan Keuangan, 4(1), 1-20.

Sari. R.A., Sutrisno., \& Sukoharsono. E.G. (2013). Pengaruh kepemilikan institusional, komposisi dewan komisaris, kinerja perusahaan terhadap luas pengungkapan corporate social responsibility di dalam sustainability report pada perusahaan manufaktur yang terdaftar di BEI. Jurnal Aplikasi Manajemen, 11(3), 481-491.

Sembiring, E.R. (2005). Karakteristik perusahaan dan pengungkapan tanggung jawab sosial: study empiris pada perusahaan yang tercatat di Bursa Efek Jakarta. Simposium Nasional Akuntansi VIII, Solo, 379-395. 
Setiawan, D., Hapsari, R.T., \& Wibawa, A. (2018). Dampak karakteristik dewan direksi terhadap pengungkapan corporate social responbility pada perusahaan pertambangan di Indonesia. Jurnal Ilmiah Manajemen, 8(1), 1-15.

Setianingsih, T., \& Setyadi, E.J. (2014). Pengaruh leverage, provitabilitas, dan ukuran perusahaan terhadap CSRD perusahaan manufaktur sektor barang konsumsi yang terdaftar di BEI (2010-2013). Kompartemen: Jurnal Ilmiah Akuntansi, 12(1),1-16.

Sudana, I.M., \& Arlindania, P.A.W. (2011). Corporate governance dan pengungkapan corporate social responsibility pada perusahaan go-public di Bursa Efek Indonesia. Jurnal Manajemen Teori dan Terapan, 4(1), 37-49.

Triyono, F., \& Setyadi, E.J. (2015). Pengaruh good corporate governance, dan pengungkapan corporate social responsibility terhadap nilai perusahaan property dan real estate yang terdaftar di BEI. Kompartemen: Jurnal Ilmiah Akuntansi, 18(1), 6483.

Velte, P. (2016). Women on management board and ESG performance. Journal of Global Responsibility, 7(1), 98-109.

Xu, E., Yang, H., Quan, J., \& Lu, Y. (2015). Organizational slack and corporate social performance: empirical evidence from China's public firm. Asia Pasific Journal of Management, 32 (1), 181-198.

Yusuf, Y.Y., Rahman, A.F., \& Mardiati, E. (2017). Determinan pengungkapan CSR dan pengaruhnya terhadap nilai perusahaan. Jurnal Bisnis dan Manajemen, 4(2), 197-216. 